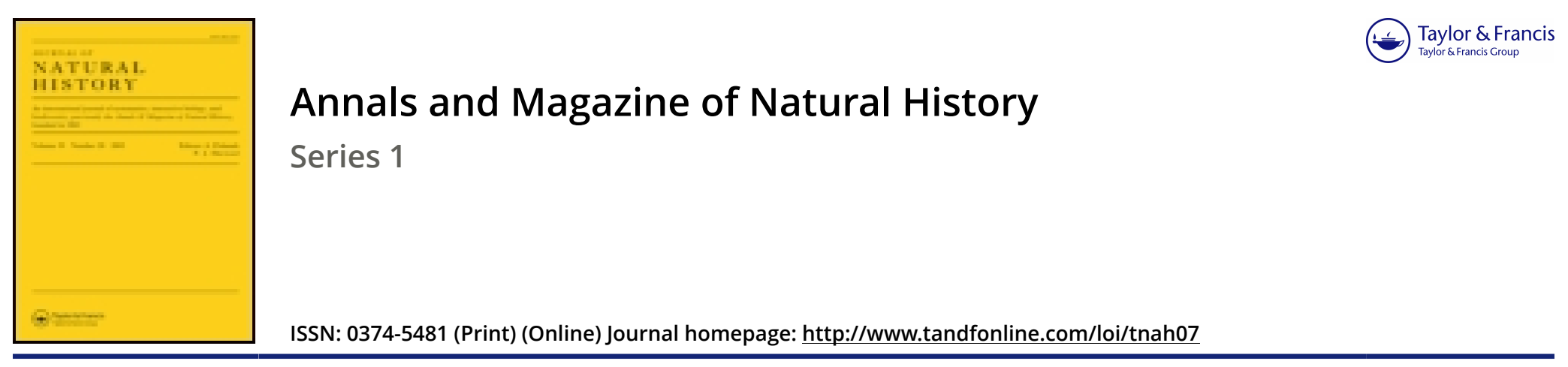

\title{
LI.-On the species of Chalcidites inhabiting the arctic region
}

\section{Francis Walker Esq. F.L.S.}

To cite this article: Francis Walker Esq. F.L.S. (1844) LI.-On the species of Chalcidites inhabiting the arctic region, Annals and Magazine of Natural History, 14:93, 407-410, DOI: 10.1080/037454809495210

To link to this article: http://dx.doi.org/10.1080/037454809495210

册 Published online: 16 Dec 2009.

Submit your article to this journal $\sqsubset \pi$

Q View related articles $\sqsubset$

4 Citing articles: 3 View citing articles 진 
tutes a kind of little utricle with rather thick walls, truncated and open at the summit; while the placenta, elongating and growing proportionally, forms a small ovoid body which exactly fills the cavity of this young ovary, but without exhibiting the slightest adhesion to its walls. In this state it resembles a young solitary ovule.

"A new modification now soon presents itself and becomes more and more marked. The little ovarian utricle contracts as it increases in length; thus its orifice in a short time becomes elevated to the summit of a little truncated cone, which is the commencement of the style. At the same time the young placenta is a little contracted towards its free extremity, so that its form is now turbinated, and its point generally fills up the inferior opening of the styliferous canal. Its surface, which until then had remained smooth, quickly swells into little rounded papillæ which are the commencement of the ovules. These ovules in Dodecatheon, Primula and Cortusa are numerous and arranged spirally."

These facts, of which the commissioners (M. A. Brongniart, M. A. Richard and M. Gaudiçhand) guarantee the exactness, sufficiently prove that in the Primulacea the placenta has a basilar origin ; that it is developed as an internal verticil without any adhesion either to the walls or summit of the ovary ; that it is there isolated like the nucleus of an ovule, or rather like a terminal spine; this evidently proves the spiral arrangement of the ovules, and still better, a little terminal flower perfectly formed, observed by M. Duchartre in Cortusa Matthioli.

This important memoir contains many delicate observations and curious facts, but as to give these would be to reproduce the memoir itself, the commissioners confine themselves to drawing attention to the capital fact of the free central placenta altogether independent of the walls and summit of the ovary, which is fully demonstrated, and to declaring that all M. Duchartre has described and figured is incontestably true.

LI.-On the species of Chalcidites inhabiting the Aretic Region. By Francis Walker, Esq., F.L.S.

[Continued from p. 342.]

Encyrtus Cleone, fem. Viridis, scutello cupreo, antennis pedibusque favis, parapteris albis, alis limpidis. (Corp. long. lin. $\frac{3}{4}$; alar. lin. $1 \frac{1}{2}$.)

Body conrex, bright green, minutely squameous : head large, transverse, slightly impressed in front, a little broader than the thorax : eyes round, red, rather large and prominent: ocelli form- 
ing a triangle on the vertex : antennæ yellow, very slender, slightly increasing in breadth towards their tips, as long as the thorax; first joint very long and slender ; second cyathiform; third very minute, hardly visible ; fourth joint narrower than the second; fifth and following joints to the ninth successively increasing in breadth; club fusiform, fulvous, a little broader than the ninth joint, and more than twice its length : thorax oval : prothorax transverse, extremely short, hardly visible above: scutum of the mesothorax large, broader than long; parapsides forming one segment with the scutum, their sutures not visible; paraptera large, white ; axillæ triangular, narrow, almost meeting each other on the dorsum; scutellum somewhat rhomboidal, cupreous, more shining than the scutum, narrower and abruptly decumbent behind where it forms a right angle: metathorax with the propodeon and podeon transverse, very short : abdomen bluish green, nearly round, much shorter and a little broader than the thorax; metapodeon large; octoon and following segments short: legs long, slender, pale yellow; tips of the tarsi fulvous; mesopedes dilated as usual : wings long, white; nervures fulvous; humerus shorter than half the length of the wing; ulna none; radius very short; cubitus much longer than the radius; stigma small, emitting no branch.

Found in the summer at Alten in Finmark.

Entedon Epigonus, Monog. Chalciditum, i. 112. Alten, Finmark. Amyite, Monog. Chal, i. 65. Alten, Finmark. Altadas, Monog. Chal. i. 70. Alten, Finmark.

Horismenus Clinus, mas. Cupreus viridi varius, antennis nigris, pedibus viridibus, tarsis flavis, alis fuscis. (Corp. long. lin. 1 ; alar. lin. $1 \frac{3}{4}$.)

Body slender, convex, cupreous, tinged with green, shining : head and thorax finely punctured : head transverse, as broad as the thorax ; vertex rather broad; front slightly impressed : eyes of moderate size, not prominent: antennæ 7 -jointed, black, slightly setaceous, as long as the thorax; first joint long, stout, increasing in breadth from the base to the tip; second cyathiform, rather small; third and following joints broader than the 2 nd; ninth joint longer and narrower than the sixth, acuminate at the tip : thorax oval : prothorax transverse, very short: scutum of the mesothorax rather large; sutures of the parapsides very distinct, approaching each other behind; axilla small, not conniving; scutellum obconical : metathorax transverse, very short: propodeon large, obconical, declining: podeon short, stout : abdomen conical, depressed, smooth, not more than half the length of the thorax; metapodeon occupying rather less than half the dorsum; octoon and following segments to the telum very short: legs slender, green; trochanters, knees and protarsi fuscous; mesotarsi and metatarsi yellow, their tips fuscous : wings slightly fuscous, dark beneath the ulna; nervures piceous; humerus not more than one-third of the length of the wing; ulna Jonger than the humerus; radius very short; cubitus a little shorter than the radius; stigma small.

Alten, Finmark. 
Omphale Atius, Entedon AEtius, Monog. Chal. i. 78. Alten, Finmark.

Euderus Amphis, Entedon Amphis, Monog. Chal. i. 106. Alten, Finmark.

Tetrastichus Tyrtieus, Cirrospilus Tyrtieus, Monog. Chal.i. 306. Alten and Hammerfest, Finmark.

Tetrastichus Faucula, Cirrospilus Faucula, Monog. Chal. i. 310. Alten, Finmark.

Tetrastichus Lachares, Cirrospilus Lachares, Monog. Chal, i. 309. Alten, Finmark.

Tetrastichus Phineus, Cirrospilus Phineus, Monog. Chal. i. 303. Alten, Finmark.

Tetrastichus Idothea, fem. Cyaneus aneo et viridi varius, abdomine cupreo aut purpureo, antennis nigris, pedibus fulvis piceo aut nigro

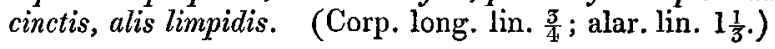

Body slender: head and thorax convex, finely squameous : head transverse, blue, as broad as the thorax; vertex broad, æneous-green; front impressed : eyes of moderate size, not prominent : antennæ black, slender, slightly setaceous, as long as the thorax ; first joint long, slender, slightly curved ; second cyathiform ; fourth and following joints successively narrower : thorax elliptical : prothorax transverse, very short: scutum of the mesothorax broad, blue; sutures of the parapsides distinct, approaching each other; scutellum obconic, æneous-green; axillæ not complete: metathorax very short: propodeon green, obconic, declining, of moderate size : podeon short: abdomen oval, cupreous, depressed above, slightly keeled beneath, rather shorter than the thorax ; metapodeon green, of moderate size; octoon and following segments transverse, short: legs fulvous, slender ; coxæ green ; a broad piceous stripe across each thigh and tibia ; tips of the tarsi piceous : wings limpid; nervures fulvous ; ulna longer than the humerus; radius very short; cubitus rather longer than the radius; stigma very small.

$\operatorname{Var}$. $\beta$. Thighs black.

Var. $\gamma$. Thighs black : abdomen purple, its base æneous.

Alten, Finmark.

Diglyphus Chabrias, Cirrospilus Chabrias, Ann. Nat. Hist. i. 451. Alten, Finmark.

Aprostocetus Catius, Cirrospilus Catius, Monog. Chal. i. 323. Alten and Hammerfest, Finmark.

Aprostocetus Anyta, Cirrospilus Anyta, Ann. Nat. Hist. iii. 417. Hammerfest, Finmark.

Dicladocerus Westwoodii, Eulophus Westwoodii, Monog. Chal. i. 157. Hammerfest, Finmark.

Eulophus Eucrate, Monog. Chal. i. 176. Hammerfest, Finmark.

Eulophus Idrieus, fem. Viridis, abdominis disco purpureo, antennis nigris, pedibus viridibus, tarsis flavis, alis limpidis. (Corp. long. lin. 1 ; alar. lin. $1 \frac{3}{4}$.)

Body slender, green, shining: head and thorax convex, finely squameous : head transverse, not quite so broad as the thorax; ver. 
tex broad ; front slightly impressed : eyes of moderate size, not prominent : ocelli disposed in a triangle on the vertex : antennæ slender, subclavate, inserted near the mouth, shorter than the thorax; first joint long, slender, slightly curved; second joint cyathiform; third, fourth and fifth joints equal in size ; club 2-jointed, conical, acuminate, longer than the fifth joint: thorax elliptical : prothorax transverse, very short; scutum of the mesothorax broad; sutures of the parapsides distinct; axillæ not complete; scutellum obconic : metathorax transverse, very short: propodeon large, obconic, declining, excavated lengthwise: podeon very short: abdomen oval, smooth, depressed above, keeled beneath, much shorter and rather broader than the thorax; the disc purple; metapodeon occupying about onethird of the dorsum; octoon and following segments to the telum transverse, short, nearly equal in size: legs green, slender; trochanters and protibia piceous; knees fulvous ; mesotarsi and metatarsi yellow, their tips piceous : wings limpid; nervures pale yellow; humerus rather short; uina longer than the humerus; radius very short; cubitus rather longer than the radius; stigma very small.

Alten, Finmark.

LII.-Notice of some additions to the British Fauna discovered by Robert MacAndrew, Esq., during the year 1844. By Professor Edwakd Fonbes of King's College, London.

\section{[With a Plate.]}

Among the many additions to the British Fauna laid before the Natural History Section of the British Association at York, some of the most interesting were exhibited by Mr. MacAndrew of Liverpool, who, though he has comparatively lately joined the ranks of Natural History, promises to do good service to British Marine Zoology. His researches have hitherto been conducted chiefly on the western coasts, especially among the Hebrides, where there is doubtless a fine field for discovery as yet but partially explored. He has entrusted to me the description of the following animals, which appear to be new to the natural history of our country.

\section{Mollusca.}

1. Emarginula crassa, Sowerby, Min. Con. t. 33.

This is the largest European species of its genus and the most beautiful. Hitherto it has been noticed only as fossil.

The shell is ovate, about twice as long as high; the apex is subcentral and acute; the upper surface is sculptured by about forty radiating fasciculated ribs, each composed of four or five smaller ones, reticulated by close furrows of growth. The notch is broad and occupies about one-fourth of the fissural ridge, which is arched, slightly elevated, longitudinally striated and regularly and closely squamated the internal cavity is smooth, and presents an elevated ridge with a central groove running from the sides 